American Journal of Applied Sciences 8 (5): 468-471, 2011

ISSN 1546-9239

(C) 2010 Science Publications

\title{
Optimal Control Design of Static Var Compensator for Damping Power System Oscillation
}

\author{
Prechanon Kumkratug \\ Department of Electrical Engineering, \\ Faculty of Engineering at Si Racha, Kasetsart University, \\ 199 M.6, Tungsukhla, Si Racha, Chonburi, 20230, Thailand
}

\begin{abstract}
Problem statement: The disturbance in power system is unavoidable situation. It causes in power system oscillation. Approach: This study applied the Static Var Compensator (SVC) to damp power system oscillation. The optimal control design is applied to derive the control strategy of SVC. The simulation results are tested on a Single Machine Infinite bus. The proposed method is equipped in sample system with disturbance. The generator rotor angle curve of the system without and with a SVC is plotted and compared. Results: It was found that the system without a SVC has high variation whereas that of the system with a SVC has much smaller variation. Conclusion: From the simulation results, the SVC can damp power system oscillation.
\end{abstract}

Key words: Power system oscillation, static var compensator, static synchronous compensator, static synchronous series compensator, unified power flow controller, inter-line power flow controller, control strategy, optimal control

\section{INTRODUCTION}

The continuously growing demand for electric power requires transmitting larger amounts of power transfer without building new transmission line. With the increased loading in modern power system, power system is getting risk. The blackout occurred in North American in 2003 challenges power engineering to find the new method for enhancing dynamic performance of power system. Flexible AC Transmission System (FACTS) controllers, based on the rapid development of power electronics technology, have been proposed for power flow control in steady state and dynamic state. The various forms of FACTS devices are the Static Var Compensator (SVC), Thyristor Controlled Phase Shifter Transformer (TCPST), Thyristor Controller Series Capacitor (TCSC), Static Synchronous Compensator (STATCOM), Static Synchronous Series Compensator (SSSC), Unified Power Flow Controller (UPFC) and Inter-line Power Flow Controller (IPFC) (Barbuy et al., 2009; Kumkratug, 2011; Rudez and Mihalic, 2009).

The control strategy of FACTS devices plays an important role for effective improvement of dynamic performance of a power system. Many research used in linear control schemes of SVC for this purposes. However, modern power system is a large and complex network and disturbances usually cause in nonlinear response (Ahmad and Mohamed, 2009; Hafaifa et al.,
2009; Amir et al., 2010; Samimi et al., 2009; Majee and Roy, 2010; Zacharie, 2009; Bagher et al., 2009; Chamsai et al., 2010).

This study presents the control strategy of a SVC for improving power system dynamic performance. The concept of optimal control is applied to derive control of SVC. The control strategy is then applied to a SVC placed in a power system to investigate the improvement of the power system dynamic performance.

\section{MATERIALS AND METHODS}

Mathematical model: Consider a single machine infinite bus system is equipped with a SVC at bus $m$ as shown in Fig. 1a. The dynamics of the machine, in classical model, can be expressed by the following differential Eqn. 1-3:

$$
\begin{aligned}
& \dot{\delta}=\omega \\
& \dot{\omega}=\frac{1}{\mathrm{M}}\left[\mathrm{P}_{\mathrm{m}}-\mathrm{P}_{\mathrm{e}}^{\mathrm{sh}}\right]
\end{aligned}
$$

Here:

$\delta, \omega, \mathrm{P}_{\mathrm{m}}$ and $\mathrm{M}=$ The rotor angle, speed, input mechanical power and moment of inertia, respectively, of the machine

$\mathrm{P}_{\mathrm{e}}^{\mathrm{sh}}=$ Output electrical power of machine with the SVC 
Without the SVC, the electrical output power of the machine $\left(\mathrm{P}_{\mathrm{e} 0}\right)$ can be expressed as:

$\mathrm{P}_{\mathrm{eo}}=\mathrm{E}^{\prime} \mathrm{V}_{\mathrm{b}} \mathrm{B}_{\mathrm{o}} \sin \delta$

Here:

$\mathrm{E}^{\prime}$ and $\mathrm{V}_{\mathrm{b}}=$ The machine voltage behind transient reactance and infinite bus voltage, respectively

$\mathrm{B}_{0} \quad=$ The transfer susceptance between the machine internal bus and the infinite bus

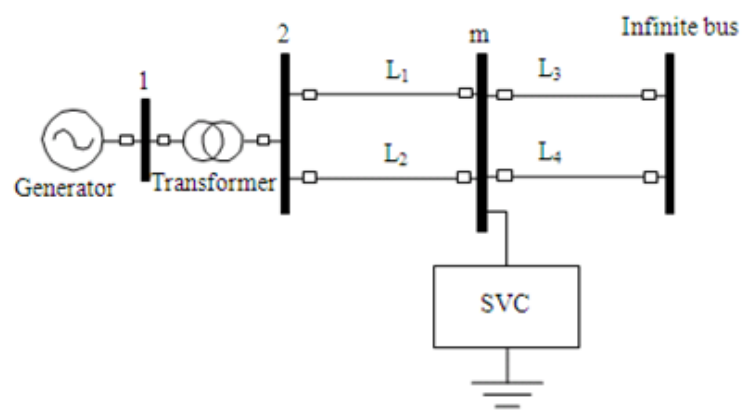

(a)

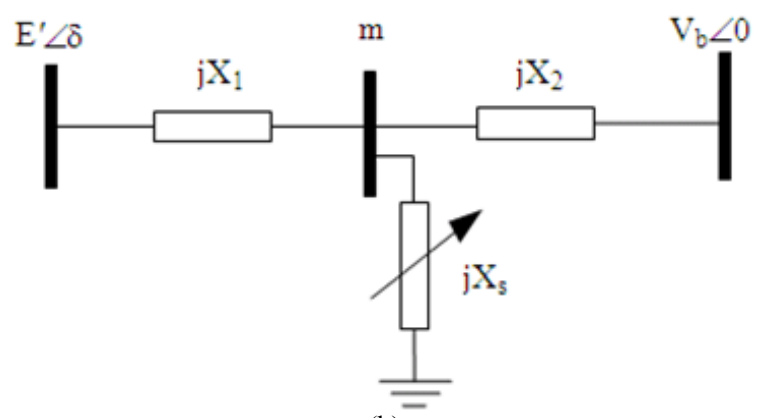

(b)

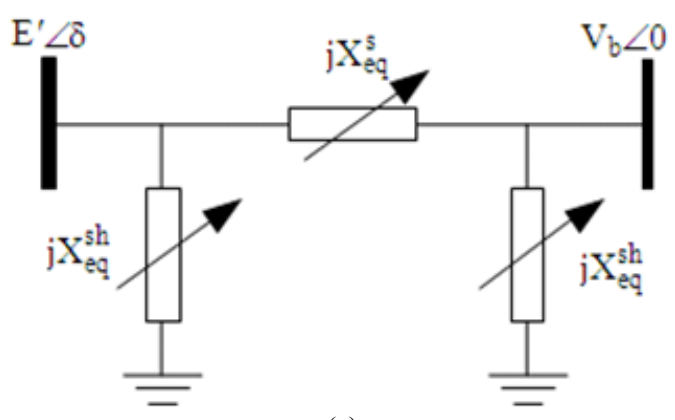

(c)

Fig. 1: A Single Machine Infinite Bus (SMIB) system (a) single line diagram (b) Equivalent circuit of system with SVC (c) Equivalent circuit after star-delta transformation
The transfer susceptance is given by:

$$
\mathrm{B}_{\mathrm{o}}=\frac{1}{\mathrm{X}_{1}+\mathrm{X}_{2}}
$$

Here:

$\mathrm{X}_{1}=$ The sum of the machine transient reactance and transformer leakage reactance

$\mathrm{X}_{2}=$ The equivalent reactance of the lines between bus $\mathrm{m}$ and the infinite bus

Thus without a SVC, the system dynamic equation, in general form, can be written as Eqn. 5:

$\dot{\mathrm{x}}=\mathrm{f}_{0}(\mathrm{x})$

Where:

$$
\begin{aligned}
& \mathrm{x}=\left[\begin{array}{l}
\mathrm{x}_{1} \\
\mathrm{x}_{2}
\end{array}\right]=\left[\begin{array}{l}
\delta \\
\omega
\end{array}\right] \text { and } \\
& \mathrm{f}_{0}(\mathrm{x})=\left[\begin{array}{l}
\mathrm{f}_{01}(\mathrm{x}) \\
\mathrm{f}_{02}(\mathrm{x})
\end{array}\right]=\left[\begin{array}{c}
\omega \\
\frac{\mathrm{P}_{\mathrm{m}}-\mathrm{P}_{\mathrm{e} 0}}{\mathrm{M}}
\end{array}\right]
\end{aligned}
$$

When a SVC is placed at bus $m$, it can be represented by a variable shunt reactance $\mathrm{X}_{\mathrm{s}}$ (or susceptance $\mathrm{B}_{\mathrm{s}}$ ) between bus $\mathrm{m}$ and ground as shown in Fig. 1b. By using star-delta transformation, Fig. 1b can be represented by its equivalent circuit as shown in Fig. 1c. In Fig. 1c, the electrical output power of the machine has no effect on the shunt reactances $X_{10}$ and $X_{20}$. However, the output power of the machine, for a given $E^{\prime}$ and $V_{b}$, depends on the transfer reactance $X_{e q}$. The value of the transfer reactance is given by:

$X_{\text {eq }}=X_{1}+X_{2}+\frac{X_{1} X_{2}}{X_{s}}$

Thus with the SVC, the electrical output power $\left(\mathrm{P}_{\mathrm{es}}\right)$ of the machine can be expressed as Eqn. 7:

$\mathrm{P}_{\mathrm{e}}^{\mathrm{sh}}=\mathrm{E}_{\mathrm{q}}^{\prime} \mathrm{V}_{\mathrm{b}} \mathrm{B}_{\mathrm{eq}} \sin \delta$

here, $B_{\text {eq }}=1 / X_{\text {eq }}$. By using Eq. 4 and $6, B_{\text {eq }}$ can be written as Eqn. 8:

$\mathrm{B}_{\mathrm{eq}}=\mathrm{B}_{0}(1+\mathrm{u})$

Where: 
Am. J. Applied Sci., 8 (5): 468-471, 2011

$\mathrm{u}=\left[\frac{\mathrm{B}_{\mathrm{s}}}{\mathrm{B}_{12}+\mathrm{B}_{\mathrm{s}}}\right]$ and $\mathrm{B}_{12}=\left[\frac{\mathrm{X}_{1}+\mathrm{X}_{2}}{\mathrm{X}_{1} \mathrm{X}_{2}}\right]$

Thus the electrical output power of the machine with a SVC, becomes:

$\mathrm{P}_{\mathrm{e}}^{\mathrm{sh}}=\mathrm{P}_{\mathrm{e} 0}+\mathrm{uP}_{\mathrm{e} 0}$

From (1), (2) and (9) Thus with the SVC, the dynamic equations of the machine can be written as:

$\dot{\mathrm{x}}=\mathrm{f}(\mathrm{x}, \mathrm{u})=\mathrm{f}_{0}(\mathrm{x})+\mathrm{uf}_{1}(\mathrm{x})$

Where:

$$
f_{1}(x)=\left[\begin{array}{c}
f_{11}(x) \\
f_{12}(x)
\end{array}\right]=\left[\begin{array}{c}
0 \\
\frac{P_{e 0}}{M}
\end{array}\right]
$$

In this study, the control strategy of dynamic Eq. 10 is investigated to improve the stability of the system.

Control strategy: The control strategy of the SVC in a single machine infinite bus system is determined from the pole-placement design method. With liberalized swing equation of Eq. 1 and Eq. 2. The new equations in state variable from are given by Eqn. 11:

$\dot{\mathrm{x}}(\mathrm{t})=\mathrm{Ax}(\mathrm{t})+\mathrm{Bu}(\mathrm{t})$

Here $\mathrm{x}$ is matrix consisting of $\delta$ and $\omega$, respectively. A and $\mathrm{B}$ is the constant matrix. The $\mathrm{u}$ is the input control strategy of SVC given by Eqn. 12:

$\mathrm{u}(\mathrm{t})=-\mathrm{Kx}(\mathrm{t})$

Here, $\mathrm{K}$ is the constant gain control.

The quadratic performance index is given by Eqn. 13:

$J=\int_{t_{0}}^{t_{t}}\left(x^{\prime} Q x+u^{\prime} R u\right) d t$

Here:

$\mathrm{R}=$ Control weight coefficient

$\mathrm{Q}=$ State weight coefficient

The minimized value of Eq. 14 can be obtained by using Lagrange multipliers method. After some mathematical manipulations, we obtains Riccati equation:

$\mathrm{PA}-\mathrm{A}^{\prime} \mathrm{P}-\mathrm{Q}+\mathrm{PBR}^{-1} \mathrm{~B}^{\prime} \mathrm{P}=0$

The gain controls the concepts of optimal control are the elements in P satisfied the Eq. 14.

\section{RESULTS}

The proposed control of a power system with a SVC is tested on system of Fig. 1a. The system data are:

$\mathrm{E}^{\prime} \angle \delta=1.23 \angle 45, \quad \mathrm{Vb}=1.0, \quad \mathrm{X}_{\mathrm{d}}^{\prime}=0.3, \quad \mathrm{X}_{\mathrm{t}}=0.1$, $\mathrm{X}_{\mathrm{L} 1}=\mathrm{X}_{\mathrm{L} 2}=0.5, \mathrm{X}_{\mathrm{L} 3}=\mathrm{X}_{\mathrm{L} 4}=1, \mathrm{H}=6, \mathrm{f}=50 \mathrm{~Hz}, \mathrm{D}=0.1$;

It is considered that a three-phase self clearing fault appears at line 1 near bus $\mathrm{m}$ and it is cleared at 140 msec. Figure 2 shows the swing curve of the system without and with a SVC based optimal control.

\section{DISCUSSION}

It can be seen in Fig. 2 that, without the SVC $(\mathrm{k}=$ 0 ), the maximum and the minimum rotor angle are around 73 and 36 degree, respectively. The damping of the system can be improved by using SVC based optimal control. With the proposed method, the maximum and the minimum rotor angle are around 68 and 43 degree, respectively and the system can return to stable equilibrium point by $2 \mathrm{sec}$.

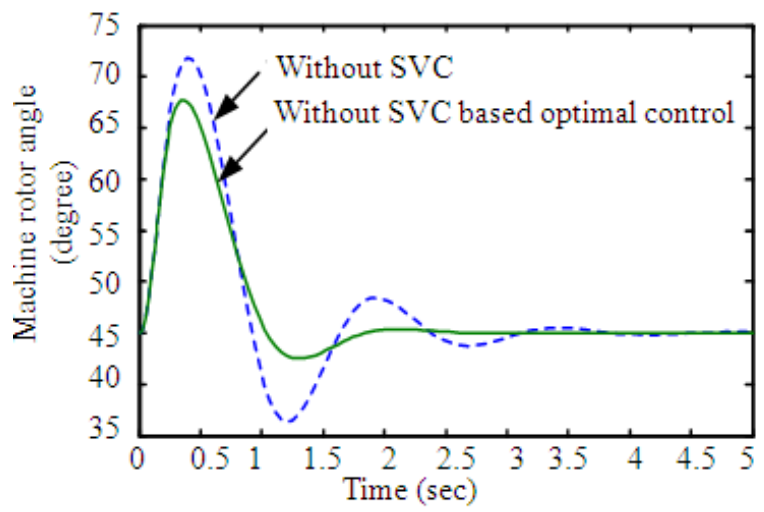

Fig. 2: Swing curve of the machine without SVC and with a SVC based optimal control 


\section{CONCLUSION}

This study presents optimal control of a Static Var Compensator (SVC) in a power system to enhance power system dynamic performance. The control strategy of the SVC is selected very carefully in the concept of optimal control. It is found that the SVC control depends on both nonlinear function of machine angle and speed. The simulation results are tested on Single Machine Infinite Bus (SMIB) system. From the simulation results, it was fond that the SVC with proposed control strategy can improve power system dynamic performance.

\section{REFERENCES}

Ahmad, M.A. and Z. Mohamed, 2009. Hybrid fuzzy logic control with input shaping for input tracking and sway suppression of a gantry crane system. Am. J. Eng. Applied Sci., 2: 241-251. DOI: 10.3844/ajeassp.2009.241.251

Bagher, M., B. Sharifian, M.R. Feyzi, S.H. Hosseini and R. Valinia, 2009. Implementing a vector controller using $68 \mathrm{k}$ processors. Am. J. Eng. Applied Sci., 2: 488-493. DOI: 10.3844/ajeassp.2009.488.493

Barbuy, H.S., A. Rocco, L.A.P. Fernandes and G.C. Guimaraes, 2009. Voltage collapse risk associated to under-voltage capacitive compensation in electric power system operation. Am. J. Applied Sci., 6: 646-651. 10.3844/ajassp.2009.646.651
Chamsai, T., P. Jirawattana and T. Radpukdee, 2010. Sliding mode control with pid tuning technique: An application to a DC servo motor position tracking control. Energy Res. J., 1: 55-61. DOI: 10.3844/erjsp.2010.55.61

Hafaifa, A., F. Laaouad and M. Guemana, 2009. A new engineering method for fuzzy reliability analysis of surge control in centrifugal compressor. Am. J. Eng. Applied Sci., 2: 676-682. DOI: 10.3844/ajeassp.2009.676.682

Kumkratug, P., 2011. Nonlinear control design of series facts devices for damping power system oscillation. Am. J. Applied Sci., 8: 124-128. DOI: 10.3844/ajassp.2011.124.128

Majee, M.C. and A.B. Roy, 2010. Asymptotic behavior of an artificial neural network defined on multipartite directed graph. OnLine J. Biol. Sci., 10: 44-49. DOI: $10.3844 /$ ojbsci.2010.44.49

Rudez, U. and R. Mihalic, 2009. Dynamic analysis of transition into island conditions of Slovenian power system applying underfrequency load shedding scheme. Proceedings of the IEEE Bucharest Power Tech Conference, June 28-2 July, IEEE Xplore, Bucharest, pp: 1-6. DOI: 10.1109/PTC.2009.5282175

Samimi, A., H.Z. Aashtiani and A.K. Mohammadian, 2009. A shor-term management strategy for improving transit network efficiency. Am. J. Applied Sci., 6: 241-246. DOI: 10.3844/ajassp.2009.241.246

Zacharie, M., 2009. Intelligent OkiKoSenPBX1 security patrol robot via network and map-based route planning. J. Comput. Sci., 5: 79-85. DOI: $10.3844 /$ jcssp.2009.79.85 